Int. J. Dev. Biol. 58: 585-591 (2014)

doi: $10.1387 / \mathrm{ijdb} .140090 \mathrm{sm}$

\title{
From trochophore to pilidium and back again - a larva's journey
}

\author{
SVETLANA A. MASLAKOVA* and TERRA C. HIEBERT \\ Oregon Institute of Marine Biology, University of Oregon, OR, USA
}

\begin{abstract}
Nemerteans, a phylum of marine lophotrochozoan worms, have a biphasic life history with benthic adults and planktonic larvae. Nemertean larval development is traditionally categorized into direct and indirect. Indirect development via a long-lived planktotrophic pilidium larva is thought to have evolved in one clade of nemerteans, the Pilidiophora, from an ancestor with a uniformly ciliated planuliform larva. Planuliform larvae in a member of a basal nemertean group, the Palaeonemertea, have been previously shown to possess a vestigial prototroch, homologous to the primary larval ciliated band in the trochophores of other spiralian phyla, such as annelids and mollusks. We review literature on nemertean larval development, and include our own unpublished observations. We highlight recent discoveries of numerous pilidiophoran species with lecithotrophic larvae. Some of these larvae superficially resemble uniformly ciliated planuliform larvae of other nemerteans. Others possess one or two transverse ciliary bands, which superficially resemble the prototroch and telotroch of some spiralian trochophores. We also summarize accumulating evidence for planktotrophic feeding by larvae of the order Hoplonemertea, which until now were considered to be lecithotrophic. We suggest that 1 ) non-feeding pilidiophoran larval forms are derived from a feeding pilidium; 2) such forms have likely evolved many times independently within the Pilidiophora; 3) any resemblance of such larvae to the trochophores of other spiralians is a result of convergence and that 4) the possibility of planktotrophy in hoplonemertean larvae may influence estimates of pelagic larval duration, dispersal, and population connectivity in this group.
\end{abstract}

KEY WORDS: nemertea, larval development, lecithotrophy, planktotrophy

\section{Introduction}

The purpose of this review is to summarize recent progress in studies of nemertean development, highlighting underappreciated aspects of larval biology in this group of spiralians, such as feeding by the juvenile-like larvae of the Hoplonemerteans, and the apparently widespread occurrence of lecithotrophic development within the Pilidiophora, including several types of larvae that convergently resemble trochophores of other spiralians.

Nemerteans are a phylum of mostly marine predatory worms, with some 1275 described species (Kajihara et al., 2008). Nemerteans possess classical equal spiral cleavage (Henry and Martindale 1998; Maslakova et al., 2004a). Anatomical, ultrastructural and phylogenetic evidence suggests that they are related to the coelomate Lophotrochozoa/Spiralia (Turbeville and Ruppert 1985; Turbeville 1986, 1991; Turbeville et al., 1992; Giribet et al., 2000; Peterson and Eernissee 2001; Struck and Fisse 2008), with, somewhat puzzlingly, increasing phylogenomic support for a sister relationship with the Lophophorate phyla (phoronids, brachiopods, and ectoprocts) (e.g. Dunn et al., 2008; Bourlat et al., 2008; Hejnol et al., 2009; Nesnidal et al., 2013), rather than the groups that actually exhibit spiral cleavage (e.g. annelids and mollusks). The adults inhabit a variety of benthic habitats from intertidal mudflats and rocky shores to the deep sea, and one group has adopted a holopelagic existence.

Like most benthic marine invertebrates nemerteans have a biphasic life cycle with a planktonic larval stage. For the sake of simplicity, nemertean larvae are typically categorized into "direct" and "indirect-developers". In this context, "direct" refers to a variety of developmental strategies from incapsulated benthic development to long-lived planktonic macrophagous larvae that feed on metazoan prey, e.g. larvae of other marine invertebrates (Norenburg and Stricker 2002). The reason these are all lumped together under the term "direct development" is, that even when a planktonic stage is present, these so-called planuliform larvae are uniformly ciliated (except for the prominent blade-like apical

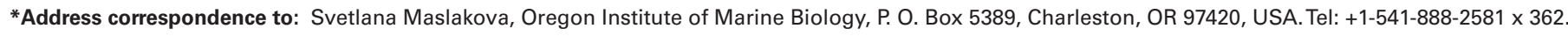
Fax: +1-541-888-3250. E-mail: svetlana@uoregon.edu
}

Accepted: 20 June 2014.

ISSN: Online 1696-3547, Print 0214-6282 

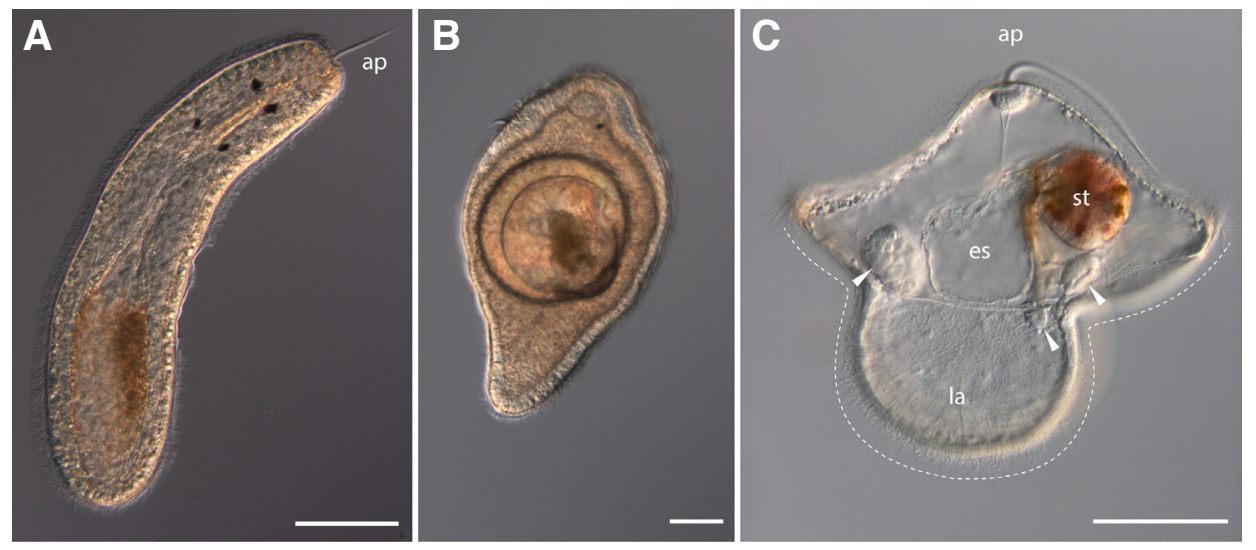

Fig. 1. Larval forms of the three major groups of nemerteans: Hoplonemertea (A), Palaeonemertea (B) and Pilidiophora (C). Larval anterior is typically marked by a blade-like apical tuft of cilia (ap), though in advanced developmental stages of some hoplonemerteans and palaeonemerteans it may be very small (B). (A) A larva of Zygonemertes sp. (Hoplonemertea) collected as an egg from plankton in Coos Bay, $O R$, hatched in the laboratory, and identified using DNA sequence data. (B) A wild-caught larva of an undescribed species Carinina sp. (Palaeonemertea) from Coos Bay, OR, matched to an adult using DNA sequences. A single midventral anterior larval eye (at $1 \mathrm{o}^{\prime} \mathrm{clock}$ ) is characteristic for this species (adults lack ocelli). This larva preyed upon a bivalve veliger, which is still clearly visible in the gut. (C) The 3-disc stage pilidium of Micrura alaskensis reared in the laboratory from eggs of morphologically identifiable adults. Dash line indicates the primary larval ciliary band. Arrowheads point to one of each three pairs of imaginal discs, from left to right: cephalic disc, cerebral organ disc, and trunk disc. (la) lappet, (es) esophagus, (st) stomach. Scale bars 100 um.

tuft, and less prominent posterior and lateral ciliary cirri), and, essentially, juvenile-like (Fig. 1A). If they do feed at all, they do so by swallowing their large prey whole, as many adult nemerteans do (Norenburg and Stricker 2002; Maslakova 2010a, this manuscript Fig. 1B). These planktonic juveniles undergo few overt morphological changes as they transition to a benthic life style. Metamorphosis, if present at all, is gradual and inconspicuous. This type of development is found in two traditionally defined orders of nemerteans - the monophyletic Hoplonemertea, and the basal (and, possibly, paraphyletic) Palaeonemertea (Maslakova 2010a).

In contrast, one monophyletic group of nemerteans, called the Pilidiophora (which includes the order Heteronemertea and the palaeonemertean Fam. Hubrechtidae), evolved a dramatically different (and very indirect) developmental strategy - via a morphologically distinct pilidium larva (Thollesson and Norenburg 2003; Maslakova 2010a). The form, function, and development of the pilidium larva is unique among animals. The most commonly encountered pilidial form resembles a transparent deer-stalker cap with ear flaps pulled down (Fig. 1C). Although the entire surface of the pilidium is covered with cilia, there is a prominent blade-like apical tuft, and, additionally, a distinct ciliated band spanning the larval lobes and lappets. Inside the pilidium is a spacious blastocoel, and a large esophageal cavity that leads into a blind stomach. The juvenile worm develops inside the larva from a series of isolated rudiments, called imaginal discs (Fig. 1C, arrowheads), which grow and fuse around the larval stomach (Maslakova 2010b). The pilidium spends weeks to months feeding on unicellular phytoplankton, and its development culminates in a rapid (a few minutes) and catastrophic metamorphosis, in which the juvenile erupts from and, usually, devours the larval body (Fewkes 1883; Cantell 1966; Lacalli 2005; Schwartz 2009; Maslakova 2010b).

A closer look at nemertean life histories, however, reveals that it is not a simple dichotomy between the pilidial development in one clade and direct development in the rest of the phylum. Maslakova (2010a) previously highlighted the fundamental differences between the development of palaeo- and hoplonemerteans, including the presence of a transitory larval epidermis and a subtle form of metamorphosis in the hoplonemertean larvae (Maslakova and von Döhren 2009), for which she coined the name "decidula", and vestigial prototroch in the development of a palaeonemertean (Maslakova et al., 2004b). These differences may mean that indirect (i.e. pilidial-like) development evolved before the divergence of the Hoplonemertea and the Pilidiophora, and was secondarily lost in the Hoplonemertea. Presence of a vestigial prototroch in a palaeonemertean suggests that a trochophore larva may have been present in a recent common ancestor of nemerteans, and lost or
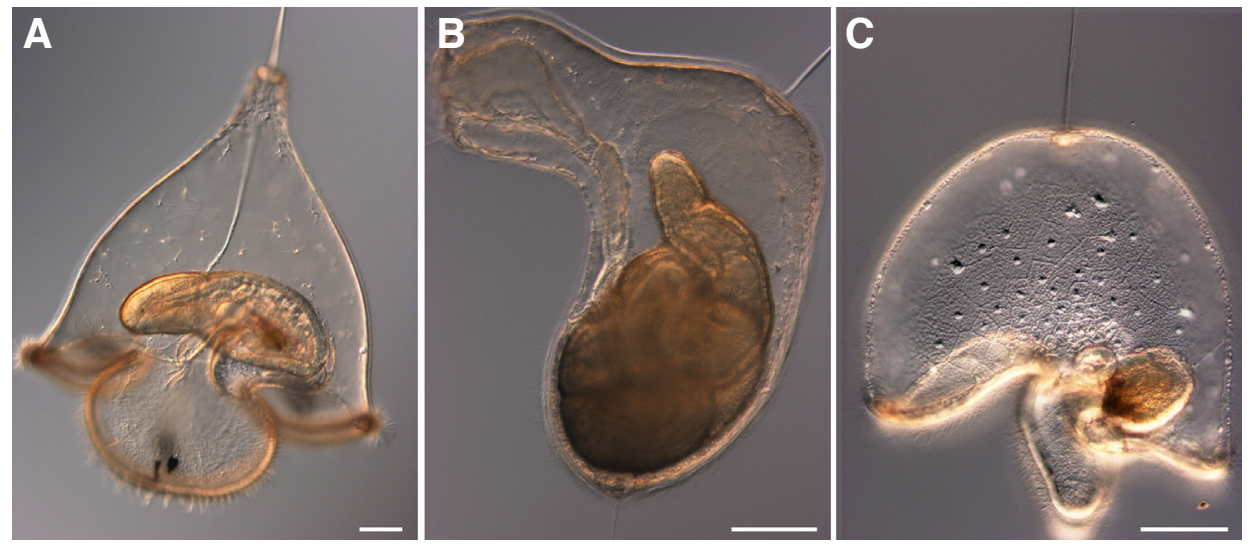

Fig. 2.The diversity of planktotrophic pilidium larvae. (A) Larvae of the Cerebratulus californiensis species complex are characterized by a mitre-shaped episphere and prominent pigment spots on the lobes and lappets. The juvenile worm inside is fully formed. (B) The sock-like pilidium recurvatum, the larva of an undescribed species Riserius sp. from Oregon, swims "heel" first with "toes" trailing behind. Note the fully formed and tightly coiled juvenile inside. (C) The mitten-like pilidium auriculatum, the larva of Hubrechtella juliae, with iconic thumb-like lappets and an inflated episphere. Larvae of this genus have characteristically conspicuous epithelial cell outlines and nuclei (highlighted here by differential interference contrast optics). All three larvae were collected in plankton samples in Coos Bay, OR, and identified using DNA sequences. Scale bars $100 \mu \mathrm{m}$ (A, B), $50 \mu \mathrm{m}$ (C). 
Fig. 3. The trochophore-like lecithotrophic pilidium nielseni. $(A),(B)$, (C) and (D) each belong to a different species, according to DNA sequence data. (A) has been matched to an undescribed species Micrura sp. "dark" from southern Oregon. (B-D) likely represent other local undescribed species. All depicted larvae were collected from plankton in Coos Bay, OR. All four have a prominent anterior apical tuft, two transverse ciliated bands (asterisks), and a ciliary cirrus
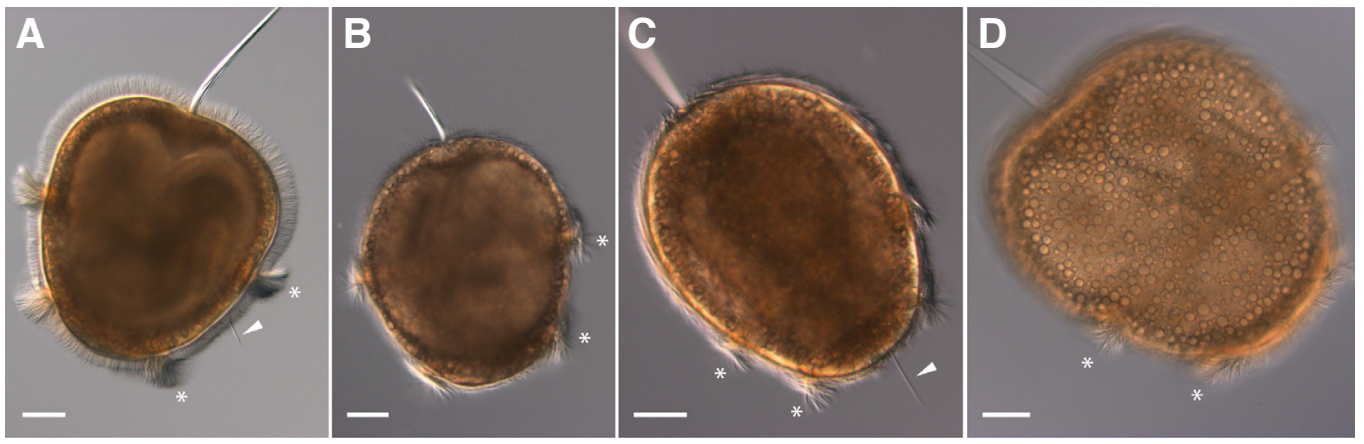

(arrowheads). A and B are similar in that the anterior-most ciliated band is roughly equatorial, and the ciliary cirrus (arrowhead on A) is located between the two transverse ciliary bands. $C$ and $D$ are similar in that the anterior-most ciliated band is about two thirds of the way toward the posterior end of the larva, and the ciliary cirrus is located at the posterior end (arrowhead on C). All four kinds have characteristic lipid droplets in the larval epidermis (in focus on D). Note the outline of the fully formed juvenile worm inside on (A), (B) and (D). Scale bars $50 \mu \mathrm{m}$.

modified beyond recognition in all but certain basal taxa. Furthermore, some pilidiophoran species are known to have lecithotrophic development in which the overall morphological resemblance to the pilidium is lost, but the juvenile development via imaginal discs and a catastrophic metamorphosis is preserved (e.g. Iwata 1958; von Döhren 2011; Schwartz and Norenburg 2005; Schwartz 2009; Maslakova and von Dassow 2012). As discussed below, accumulating evidence suggests that this type of development is much more common within the Pilidiophora than previously appreciated,and includes several morphologically (and, likely, phylogenetically) distinct types, including some that resemble trochophore larvae of other spiralians convergently.

\section{Pilidiophora}

Although the hat-like pilidium is the form most commonly encountered in plankton, it is by no means representative of the remarkable diversity of pilidiophoran larvae including both feeding and non-feeding forms.

Many long-lived planktotrophic larvae of marine invertebrates (e.g. the phoronid actinotroch, the bryozoan cyphonautes, or the echinoderm bipinnaria) look strikingly different from their benthic adults, and the pilidium is no exception. As is the case with many such larvae, the pilidium was not immediately recognized as the larval form of a nemertean, and instead described under its own taxonomic binomen Pilidium gyrans (Müller 1847). Eventually, embryologists recognized the pilidium as a larva of a nemertean (Metchnikoff 1869). Since then, plankton surveys have revealed a great diversity of planktotrophic pilidium larvae (Fewkes 1883; Dawydoff 1940; Cantell 1969; Lacalli 2005; Norenburg and Stricker 2002), but because they could not be identified to species, genus, or even a family, they were typically assigned binomena, such as Pilidium auriculatum, Pilidium recurvatum etc. We now recognize that most, if not all, of these morphotypes comprise multiple species (T. Hiebert and Maslakova, unpublished), and in order to avoid confusion with the proper species names, we do not capitalize morphotype names here.

Figure 2 illustrates some of the diversity of the planktotrophic pilidia, including the familiar hat-like form (Fig. 2A), the unusual sock-like pilidium recurvatum (Fig. 2B), and the mitten-like pilidium auriculatum (Fig. 2C). This diversity of form may be deeper than the looks. Recently, von Dassow et al., (2013) reported on a unique way that the hat-like pilidium of Micrura alaskensis utilizes its complex system of ciliary bands and muscles to detect and capture its favorite prey - cryptomonad algae. The sophisticated mechanism depends on a precise arrangement of the ciliary bands, and is unlikely to be the same for other pilidial forms, such as the recently re-described sock-like pilidium recurvatum (Hiebert et al., 2013, Fig. 2B), or the mitten-like pilidium auriculatum (Fig. 2C).

The lack of a robust comprehensive phylogeny of the Pilidiophora (about 450 described species) precludes identification of the ancestral pilidiophoran larval form. Hat-like larvae occur in a wide variety of pilidiophorans. The pilidium auriculatum is only known in one group, family Hubrechtidae, the sister clade to the rest of the Pilidiophora (Thollesson and Norenburg 2003, although see Andrade et al., 2011a). The pilidium recurvatum from the NE Pacific has recently been matched to the genus Riserius (Hiebert et al., 2013), which occupies a basal position within the non-hubrechtid pilidiophorans (Thollesson and Norenburg 2003). A similar sock-like form with a posterior transverse ciliated band (Fewkes 1883; Dawydoff 1940; Cantell 1969), or the various other unusual pilidial types (Dawydoff 1940) have not been matched to adults, and their phylogenetic position remains unknown. One thing, however, seems clear: whatever the shape, a planktotrophic pilidium is ancestral to the Pilidiophora, while lecithotrophy is derived. For one, lecithotrophic pilidiophorans undergo development with imaginal discs and catastrophic metamorphosis, thus recapitulating, in a vestigial form, a typical pilidial development. Second, larvae of this type are not all alike, morphologically, are not apparently closely related to each other, and are not clearly basal to the Pilidiophora (see below).

Ten years ago only three pilidiophoran species were known to have lecithotrophic development: Lineus viridis (encapsulated Desor's larva), its sibling species L. ruber (similarly encapsulated, but adelphophagous), and Micrura akkeshiensis (planktonic planula-like Iwata's larva) (Iwata 1958; Schmidt 1964). However, accumulating evidence suggests that this type of development may be much more common among the Pilidiophora. For example, Schwartz and Norenburg (2005) described a novel type of lecithotrophic pilidiophoran larva equipped with a trochophore-like equatorial ciliated band in Micrura rubramaculosa. A few years later, Schwartz in her dissertation (2009) reported lecithotrophic development in Micrura verrilli, and two undescribed species Micrura sp. 803 and Micrura sp. 676. In every case where the development of a lecithotrophic pilidiophoran was investigated the juvenile arises underneath the larval epidermis from a series 

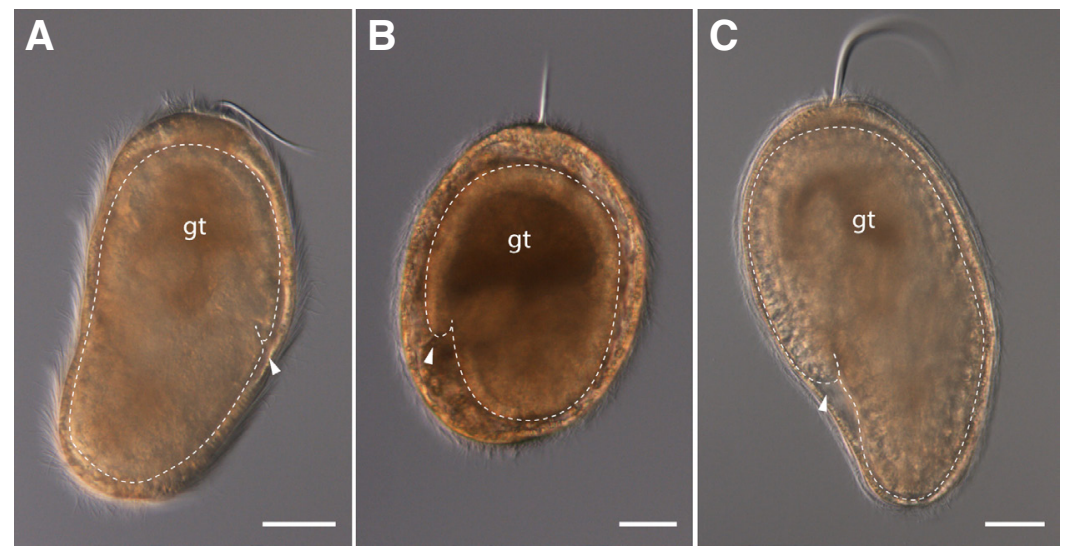

Fig. 4. The new kinds of uniformly ciliated lecithotrophic pilidia. (A-C) These were collected from plankton in Coos Bay, OR. DNA sequence data suggest that all three are distinct from each other and from Micrura akkeshiensis - the only other known uniformly ciliated lecithotrophic pilidium with reversed larval and juvenile axes. The juvenile worm inside is outlined with a dash-line, and the juvenile posterior is marked with an arrowhead. The larval anterior, marked by the apical tuft, is up, whereas the juvenile anterior is down. The juvenile gut (gt) is more opaque than the juvenile anterior, and is pointed up. Scale bars $50 \mu \mathrm{m}$.

of rudiments resembling the imaginal discs of a typical pilidium (though reported number of discs varies between species), and the larval epidermis is lost during metamorphosis (Iwata 1958; Schwartz 2009). The fact that many of these lecithotrophic larvae are assigned to the genus Micrura does not suggest a single (or dual) origin of this type of development. The genus Micrura is poorly defined by morphological characters, and is polyphyletic according to molecular phylogenies (Norenburg and Thollesson 2003; Schwartz 2009; Andrade et al., 2011a). Furthermore, Schwartz's phylogenetic analysis (2009) suggests that lecithotrophy may have evolved within the Pilidiophora at least four times.

Recently Maslakova and von Dassow (2012) reported yet another type of lecithotrophic pilidiophoran larva - this one equipped with two transverse ciliary bands superficially resembling the prototroch and telotroch of some annelid trochophores. This type of larva (named pilidium nielseni after Prof. Claus Nielsen), discovered in a plankton sample off the coast of Oregon, was initially matched to a local undescribed lineiform species (Micrura sp. "dark") using DNA sequence data (Maslakova and von Dassow 2012), and subsequently reared to metamorphosis in the laboratory from the gametes of field-collected adults (Hunt and Maslakova, unpublished). Despite a trochophore-like appearance and non-feeding development this larva undergoes rapid catastrophic metamorphosis, and the emerging juvenile devours the larval body (Maslakova and von Dassow 2012), as is typical of planktotrophic pilidia, and also reported for encapsulated larva of Lineus viridis (von Döhren 2011). To our surprise we have discovered that a similar type of larva (with a "prototroch" and "telotroch") apparently occurs in three other undescribed species in southern Oregon, all closely related, but distinct from Micrura sp. "dark" according to DNA sequence data, and larval morphology (Fig. 3; Maslakova et al., unpublished).

In addition to the four species with trochophore-like pilidium nielseni, we found three other species of lecithotrophic pilidia in Oregon plankton (Fig. 4). Although we are yet to locate their adults, DNA sequence data suggest they are distinct from each other and from other known lecithotrophic forms (T. Hiebert and Maslakova, unpublished). All three are planktonic, uniformly ciliated, and resemble Iwata's larva in that the antero-posterior (AP) axis of the juvenile is reversed with respect to the larval AP axis (i.e. juvenile anterior coincides with the larval posterior). This is in contrast to the four types of lecithotrophic pilidia described by Schwartz and Norenburg (2005) and Schwartz (2009), in which the juvenile head points the same way as the larval anterior. We suspect that at least two other undescribed lineiform species from Oregon also have lecithotrophic development. We have collected numerous adult individuals of a species to which we refer as "Lineid large eggs" intertidally at Cape Arago, some of which had well-developed gonads. Although we are yet to observe development directly, the large size of the oocytes $(\sim 500 \mu \mathrm{m}$ in diameter $)$ strongly suggests lecithotrophy, and, possibly, encapsulated development. Similarly, we have observed $\sim 300 \mu \mathrm{m}$ oocytes in two females of Micrura cf. coeicollected at Cape Arago. Eggs of Micrura sp. "dark" which develop into the trochophore-like pilidium nielseniare $260 \mu \mathrm{m}$ in diameter, and eggs of other species with reported lecithotrophic pilidia range from about $150 \mu \mathrm{m}$ to about $350 \mu \mathrm{m}$ in diameter (Iwata 1958; Schwartz and Norenburg 2005; Schwartz 2009). Eggs of $L$. ruber and $L$. viridis are $250 \mu \mathrm{m}$ and $300-400$ $\mu \mathrm{m}$ in diameter, respectively (Friedrich 1979; Schwartz 2009). In comparison, eggs of pilidiophorans known to have planktotrophic development range from 75-160 $\mu \mathrm{m}$ (Friedrich 1979; Schwartz 2009; pers. obs.).

To summarize, 16 pilidiophoran species are currently known or strongly suspected to have lecithotrophic (planktonic or encapsulated) development. Because such larvae are not typically recognized for what they are by an average plankton-sorter, and few people attempt to raise nemertean larvae in the laboratory, or identify unknown larvae from plankton using DNA sequence data, it is quite likely that there are many more species of lecithotrophic pilidiophorans. Athorough phylogenetic analysis of the Pilidiophora including all of the species known to have non-feeding larvae will help to determine how many times this type of development evolved, but preliminary data point to multiple origins (Schwartz 2009; T. Hiebert and Maslakova, unpublished).

\section{Hoplonemertea}

Hoplonemerteans comprise a monophyletic group of $\sim 570$ described species (Kajihara et al., 2008), sister to the Pilidiophora (Thollesson and Norenburg 2003; Andrade et al., 2011a). Some species have encapsulated development, while others release eggs (often loosely connected by a jelly) which develop into uniformly ciliated planuliform planktonic larvae (Maslakova and von Döhren 2009 and references therein). Maslakova (2010a) suggested a term "decidula" for the hoplonemertean larvae to emphasize the presence of the transitory larval epidermis and a subtle form of metamorphosis in hoplonemerteans (Maslakova and von Döhren 2009; Hiebert et al., 2010).

Until now hoplonemertean larvae were thought to be lecithotrophic (i.e. non-feeding) (Friedrich 1979; Striker 1987; Norenburg and Stricker 2002; Maslakova 2010a). While this is demonstrably 
the case for some species, such as Paranemertes peregrina (Maslakova and von Döhren 2009), multiple lines of evidence suggest that others may be feeding while in the plankton and, indeed, require food to develop to metamorphosis (however subtle) and settlement.

One example is the larva of Carcinonemertes errans, whose adults are parasites and egg predators on the Dungeness crab, Cancer magister (Wickham 1979). The nemertean deposits egg sheaths among the crab eggs, and the newly hatched $C$. errans larvae are $\sim 110 \mu \mathrm{m}$ long, and possess a single pair of eyes (Dunn 2011). Efforts to induce settlement in lab-reared larvae of $C$. errans or a closely related congener $C$. epialti by exposing them to a variety of potential settlement cues (including live specimens of the preferred host crab) have been unsuccessful (Roe 1979; Stricker and Reed 1981; Dunn 2011). Invariably, larvae survived for a period of time (up to several weeks) and then died. We have identified larvae of $C$. errans from plankton samples in Oregon (Fig. 5A) using DNA sequence data (Maslakova, unpublished). In contrast to lab-reared larvae these are considerably larger (0.5-1 $\mathrm{mm}$ long), darker, and possess two pairs of eyes. Remarkably, Dunn (2011) was able to induce settlement and metamorphosis in such wild-caught planktonic larvae of $C$. errans by exposing them to live Dungeness crabs. The dramatic difference in size between the newly hatched larvae and the wild-caught metamorphically competent larvae suggests that $C$. errans feed in the plankton, although how and what they eat remains a mystery.

Our recent preliminary attempts to identify gut contents of wild-caught hoplonemertean larvae, including those of $C$. errans, using PCR with taxon-specific primers suggest crustaceans as potential prey. For example, we identified sequences of Pandalus sp. from larval samples of $C$. errans, and Cancer sp. and Pinnixa faba (Maslakova et al., unpublished) from wild-caught larvae of Gurjanovella sp. (Fig. 5B). Although we lack direct evidence at the moment, we suspect that larvae (or planktonic juveniles) of certain other hoplonemerteans, such as Poseidonemertes collaris (Fig. 5C), and Ototyphlonemertes sp. (Fig. 5D) are also feeding in the plankton based on their large size and the size differences between conspecific wild-caught planktonic individuals (Maslakova and T. Hiebert, pers. obs.).

The possibility that hoplonemertean larvae can feed suggests that they may be spending a considerable amount of time in the plankton, and thus may disperse farther than previously thought. This could explain seemingly paradoxical lack of genetic differentiation between geographically isolated populations of interstitial hoplonemerteans Ototyphlonemertesspp. (Andrade et al., 2011b), which are currently thought to have short-lived larvae and limited potential for dispersal.

\section{Palaeonemertea}

The basal nemertean taxon Palaeonemertea ( 110 species) comprises families Carinomidae, Cephalotricidae and Tubulanidae, and is paraphyletic according to some molecular analyses (Thollesson and Norenburg 2003), and monophyletic according to others (Andrade et al., 2011a). This group enjoyed the least amount of embryological attention both historically and in recent times (although see Bartolomaeus et al., 2013). Maslakova et al., (2004 a,b) reported a vestigial prototroch in a palaeonemertean Carinoma. Carinoma's prototroch, although not differentially ciliated, exhibits important similarities with the prototrochs of certain annelids and mollusks, such as being composed of relatively few relatively large cleavage-arrested cells, and being derived from the classical spiralian trochoblast lineage (Damen and Dictus 1994). Thus, it is assumed to be homologous to the prototroch of other spiralians (but hidden underneath the uniform ciliation). The discovery of the vestigial prototroch in one group of palaeonemerteans and the fact that palaeonemerteans may not be monophyletic, poses the question whether this feature is unique to Carinoma (or Carinomidae) or whether it is, in fact, a basal condition for the phylum. Intriguingly, our preliminary data suggests that cephalotricids may lack a distinct prototroch as found in Carinoma (Maslakova, unpublished). Future studies need to focus on both the basic descriptive embryology of diverse palaeonemerteans, as well as on establishing palaeonemertean model systems for molecular analyses of embryonic and larval development.

\section{Concluding remarks}

Recent discoveries of novel lecithotrophic pilidia highlight convergent evolution of trochophore-like morphology in nemerteans.
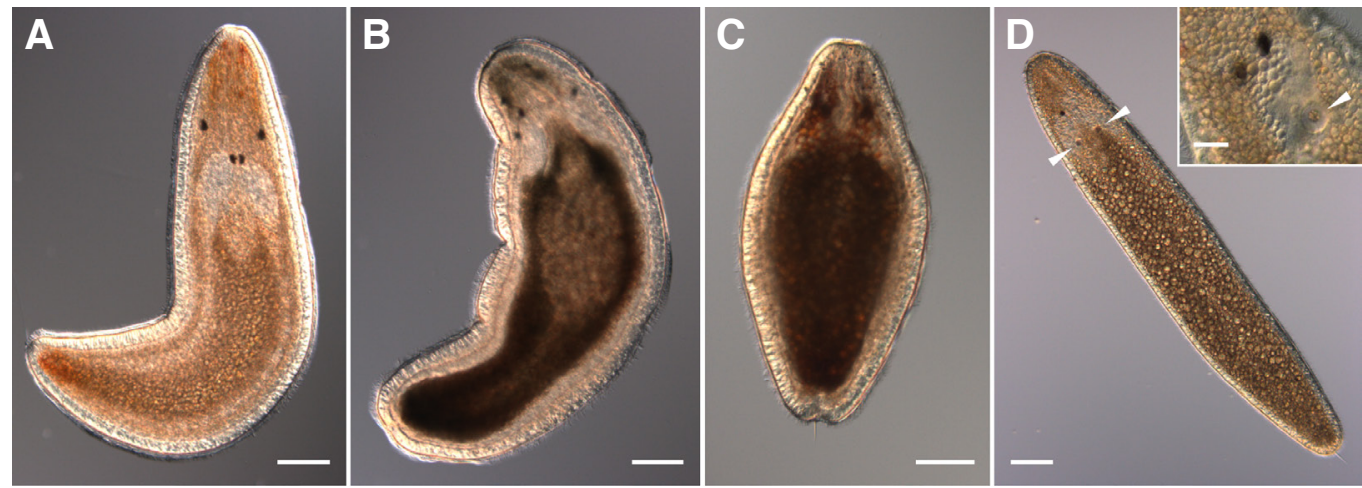

Fig. 5. Hoplonemertean larvae presumed to be feeding in the plankton. All were collected from plankton in Coos Bay, OR, and identified using DNA sequences. (A) The larva of Carcinonemertes errans. Note the characteristic pinkish-orange color and eye arrangement with a widely spaced anterior pair and a closely apposed posterior pair immediately in front of the cerebral ganglia (translucent areas). Posterior eyes usually appear as a single ocellus, unless the larva is compressed under coverslip, as is the case here. PCR with taxon-specific primers suggests C. errans larvae may feed on crustaceans. (B) The larva of Gurjanovella sp. PCR with taxonspecific primers suggests this individual may have recently fed on a pea crab (Pinnixa faba). (C) The larva of Poseidonemertes collaris. Wild-caught larvae determined to belong to this species ranged from $600 \mu \mathrm{m}$ to $1100 \mu \mathrm{m}$ in length, which suggests that they grow and, therefore, feed in the plankton. (D) The larva of Ototyphlonemertes sp. Note the characteristic paired statocysts (arrowheads, also inset) in the cerebral ganglia. Ototyphlonemertes has a pair of larval eyes (adults lack eyes), but the larva on (D) had only one. Inset shows cerebral region of another individual with two eyes and a single statocyst in focus. The relatively large size of the larva on (D) suggests that it may be feeding in the plankton. Scale bars $100 \mu \mathrm{m}(20 \mu \mathrm{m}$ on inset). 
Larvae of Micrura rubramaculosa (Schwartz and Norenburg 2005) and pilidium nielseni (Maslakova and von Dassow 2012, this manuscript Fig. 3) are apparently derived from a planktotrophic pilidium, which, as parsimony suggests, in turn evolved within the Nemertea from a uniformly ciliated and, possibly, trochophore-like ancestral larval form (Maslakova 2004a,b; Schwartz 2009; Maslakova 2010a). The "prototroch" of pilidium nielseni is, morphologically, very different from the "hidden" prototroch in Carinoma, being composed of numerous small cells (Fig. 6), which supports our hypothesis of convergent origin. If a trochophore-like larva (such as found in Carinoma) represents the ancestral condition for the phylum Nemertea, then the envisioned evolutionary transition would go from the trochophore to pilidium (in Pilidiophora) and back to the trochophore-like morphology in select pilidiophoran taxa such as the Micrura sp. "dark" species group and Micrura rubramaculosa. This hypothesis would be further supported if one could show, for example, an ontogenetic transformation of a single circum-blastoporal ciliary band into two transverse ciliary bands of the pilidium nielseni. Ontogenetic re-arrangement of a single larval ciliary band or a uniform ciliary field into several transverse rings has been shown in holothuroid and crinoid echinoderms (Lacalli and West 1986, 2000; Nakano et al., 2003). Perhaps, spiralians are not immune to such developmental or evolutionary transformations either.

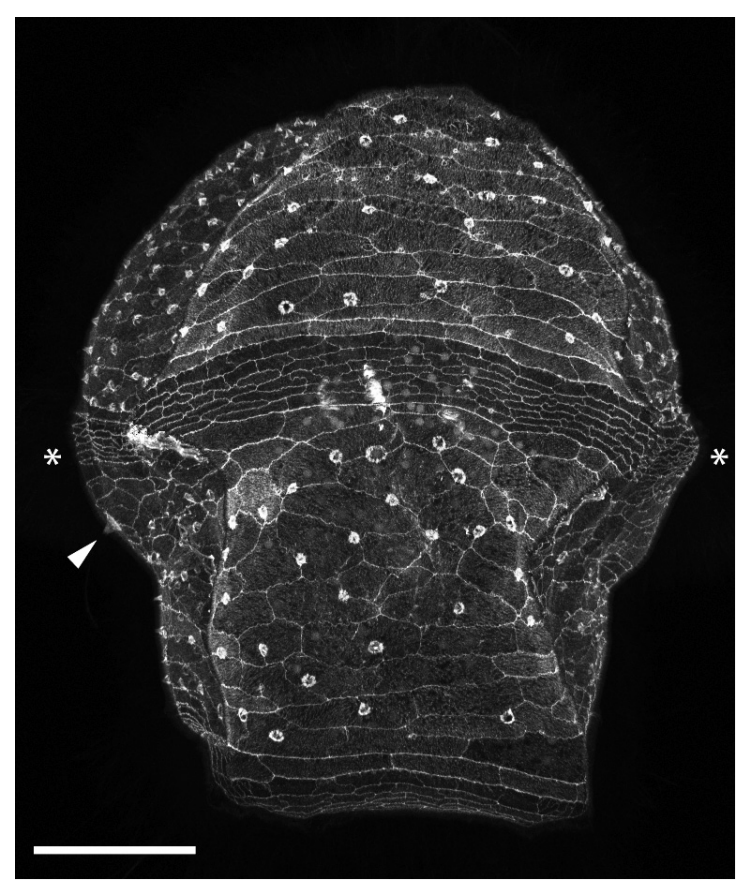

Fig. 6. The "prototroch" in pilidium nielseni. A confocal z-projection of a phalloidin-labeled lecithotrophic larva of Micrura sp. "dark." Note the six or so rows of tiny cells (smaller than the cells of adjacent epidermis) that compose the "prototroch" (asterisks). Larval anterior is up. The ciliary cirrus (arrowhead) is visible just posterior to the "prototroch." In order to highlight the epidermal cell outlines (without interference from the larval muscles), the image was made as a composite of two separate $z$-projections of the same stack. The top $10 \mu \mathrm{m}$ are projected separately from the rest of the $147 \mu \mathrm{m}$ stack to exclude the muscles. Projection of the thin surface slab (100\% opacity) is overlaid onto the projection of the rest of the stack. Scale bar $50 \mu \mathrm{m}$.

\section{Acknowledgements}

We thank undergraduate and graduate students who participated in DNA-identification of larval nemerteans (and their potential prey) by virtue of taking the Molecular Marine Blology course annually taught by SAM at the OIMB. This work was partially supported by NSF grants IOS-1120537 to SAM and OCE-1030453 to CM Young and SAM.

\section{References}

ANDRADE SCS, STRAND M, SCHWARTZM, CHENH, KAJIHARAH, VONDÖHREN J, SUN S, JUNOY J, THIEL M, NORENBURG, JL, GIRIBET G, SUNDBERG P (2011a). Disentangling ribbon worm relationships: multi-locus analysis supports traditional classification of the phylum Nemertea. Cladistics 28: 141-159.

ANDRADE SCS, NORENBURG JL, SOLFERINI VN (2011b). Worms without borders: genetic diversity patterns in four Brazilian Ototyphlonemertes species (Nemertea, Hoplonemertea). Mar Biol 158: 2109-2124.

BARTOLOMAEUS T, MASLAKOVA S, VON DÖHREN J (2013). Protonephridia in the larvae of the paleonemertean species Carinoma mutabilis (Carinomidae, Nemertea) and Cephalothrix (Procephalothrix) filiformis (Cephalothricidae, Nemertea). Zoomorphology DOI 10.1007/s00435-013-0206-3.

BOURLAT SJ, NIELSEN C, ECONOMOU AD, TELFORD MJ (2008). Testing the new animal phylogeny: a phylum level molecular analysis of the animal kingdom. $\mathrm{Mol}$ Phylogenet Evol 49:23-31.

CANTELL C-E (1966). The devouring of the larval tissues during the metamorphosis of pilidium larvae (Nemertini). Ark Zool 18:489-92.

CANTELL C-E (1969). Morphology, development and biology of the pilidium larvae (Nemertini) from the Swedish West Coat. Zool Bidr Upps 38: 61-111.

DAMEN P, DICTUS WJAG (1994). Cell lineage of the prototroch of Patella vulgata (Gastropoda, Mollusca). Dev Biol 162:364-83.

DAWYDOFF C (1940). Les formes larvaires de polyclades et de nemertes du plankton Indochinois. Bull Biol Fr Belg 74: 443-496.

DUNN CW, HEJNOL A, MATUS DQ, PANG K, BROWNE WE, SMITH SA, SEAVER E, ROUSE GW, OBST M, EDGECOMBE GD, SØRENSEN MV, HADDOCK SHD, SCHMIDT-RHAESA A, OKUSU A, KRISTENSEN RM, WHEELER WC, MARTINDALE MQ, GIRIBET G (2008). Broad phylogenomic sampling improves resolution of the animal tree of life. Nature 452: 745-749.

DUNN PH (2011). Larval Biology and Estuarine Ecology of the Nemertean Egg Predator Carcinonemertes errans on the Dungeness Crab, Cancer magister. Department of Biology, PhD dissertation, University of Oregon, Eugene, Oregon.

FEWKES JW (1883). On the developmental stages of certain worm larvae. Bull Mus Comp Zool 11(9): 167-208.

FRIEDRICH H (1979). Nemertini In Morphogenese der Tiere [Morphogenesis of animals. Nemerteans]. VEB Gustav Fischer Verlag, Jena.

GIRIBET G, DISTELDL, POLZM, STERRER W, WHEELER WC (2000). Triploblastic relationships with emphasis on the acoelomates and the position of Gnathostomulida, Cycliophora, Plathelminthes, and Chaetognatha: A combined approach of 18S rDNA sequences and morphology. Syst Biol 49: 539-562.

HEJNOL A, OBST M, STAMATAKIS A, OTT M, ROUSE GW, EDGECOMBE GD, MARTINEZ P, BAGUÑÀ J, BAILLY X, JONDELIUS U, WIENS M, MÜLLER WEG, SEAVER E, WHEELER WC, MARTINDALE MQ, GIRIBET G, DUNN CW (2009). Assessing the root of bilaterian animals with scalable phylogenomic methods. Proc Biol Sci 276:4261-4270.

HENRY JJ, MARTINDALE MQ (1998). Conservation of the spiralian developmental program: cell lineage of the nemertean, Cerebratulus lacteus. Dev Biol 201:253-269.

HIEBERT LS, GAVELIS GS, VON DASSOW G, MASLAKOVA SA (2010). Five invaginations and shedding of the larval epidermis during development of the hoplonemertean Pantinonemertes californiensis. J Nat Hist 44:2331-2347.

HIEBERT TC, VON DASSOW G, HIEBERT LS, MASLAKOVA SA (2013). The peculiar nemertean larva pilidium recurvatum belongs to Riserius sp., a basal heteronemertean that eats Carcinonemertes errans, a hoplonemertean parasite of Dungeness crab. Invertebr Biol 132(3): 207-225.

IWATA F. (1958). On the development of the nemertean Micrura akkeshiensis Embryologia 4:103-131.

KAJIHARA H, CHERNYSHEV AV, SUN S, SUNDBERG P, CRANDALL F (2008). Checklist of nemertean genera and species published between 1995 and 2007. 
Species Div 13:245-274.

LACALLI TC, WEST JE (1986). Ciliary band formation in the doliolaria larva of Florometra. I The development of normal epithelial pattern. J Embryol Exp Morph 96: 303-323.

LACALLI TC, WEST JE (2000). The auricularia-to-doliolaria transformation in two aspidochirote holothurians, Holothuria mexicana and Stichopus californicus. Invert Biol 119: 421-432.

LACALLI TC (2005). Diversity of form and behaviour among nemertean pilidium larvae. Acta Zool 88:267-276.

MASLAKOVASA, MARTINDALEMQ, NORENBURG JL(2004a). Fundamental properties of the spiralian developmental program are displayed by the basal nemertean Carinoma tremaphoros (Palaeonemertea, Nemertea). Dev Biol 267: 342-360.

MASLAKOVASA, MARTINDALE MQ, NORENBURG JL (2004b) Vestigial prototroch in a basal nemertean, Carinoma tremaphoros (Nemertea; Palaeonemertea). Evol Dev 6:219-226.

MASLAKOVASA, VONDÖHRENJ (2009). Larval development with transitory epidermis in Paranemertes peregrinaand other hoplonemerteans. Biol Bull216:273-292.

MASLAKOVASA (2010a). The invention of the pilidium larva in an otherwise perfectly good spiralian phylum Nemertea. Integ Comp Biol 50: 734-743.

MASLAKOVASA (2010b). Development to metamorphosis of the nemertean pilidium larva. Front. Zool. 7:30.

MASLAKOVA SA, VON DASSOW G (2012). A lecithotrophic pilidium with apparent prototroch and telotroch. J Exp Zool B Mol Dev Evol 10: 47.

METCHNIKOFF E (1869). Studien über die entwicklung der echinodermen und nemertinen. Mem Acad Sci St Pters Ser 7 14: 49-65.

MÜLLER J (1847). Über einige neue Thierformen der Nordsee. Arch Anat Physiol: 157-179.

NAKANO H, HIBINO T, OJI T, HARA Y, AMEMIYA S (2003). Larval stages of a living sea lily (stalked crinoid echinoderm). Nature 421: 158- 160.

NESNIDAL MP, HELMKAMPF M, MEYER A, WITEK A, BRUCHHAUS I, EBERSBERGER I, HANKELN T, LIEB B, STRUCK TH, HAUSDORF B (2013). New phylogenomic data support the monophyly of Lophophorata and an EctoproctPhoronid clade and indicate that Polyzoa and Kryptrochozoa are caused by systematic bias. BMC Evol Biol 13: 253.

NORENBURG JL and STRICKER SA (2002). Nemertea. In Atlas of Marine Invertebrate Larvae (Eds Young CM, Sewall MA and Rice ME). Academic Press, San Diego, pp. 163-177.

PETERSON KJ, EERNISSEE DJ (2001). Animal phylogeny and the ancestry of the bilaterians: Inferences from morphology and 18S rDNA sequences. Evol Dev 3:170-205.
ROE P (1979). Aspects of development and occurence of Carcinonemertes epialti (Nemertea) from shore crabs in Monterey Bay, California. Bio Bull 156: 130-140.

SCHMIDT GA (1964). Embryonic development of littoral nemertines Lineus desori (mihi, species nova) and Lineus ruber (O. F. Mülleri, 1774, G. A. Schmidt, 1945) in connection with ecological relation changes of mature individuals when forming the new species Lineus ruber. Zool Poloniae 14:75-122.

SCHWARTZ ML, NORENBURG JL (2005). Three new species of Micrura (Nemertea: Heteronemertea) and a new type of heteronemertean larva from the Caribbean Sea. Caribb J Sci 41:528-543.

SCHWARTZ, ML (2009). Untying a Gordian Knot of Worms: Systematics and Tax onomy of the Pilidiophora (phylum Nemertea) from Multiple Data Sets. Columbian College of Arts and Sciences. Ph.D thesis. The George Washington University, Washington, DC Ann Arbor: ProQuest/UMI. (Publication No. 3339279).

STRUCK TH AND FISSE F (2008). Phylogenetic position of Nemertea derived from phylogenomic data. Mol Biol Evol 25: 728-736

STRICKERSA (1987). Phylum Nemertea In Reproduction and development of marine invertebrates of teh northern Pacific coast: Data and methods for the study of eggs, emrbyos, and larvae (Ed Strathmann, M). University of Washington Press, Seattle. pp. 129-137.

STRICKER SA, REED CG (1981). Larval morphology of the nemertean Carcinonemertes epialti (Nemertea: Hoplonemertea). J Morph 169: 61-70.

THOLLESSONM, NORENBURG JL (2003). Ribbon worm relationships-a phylogeny of the phylum Nemertea. Proc $R$ Soc Lond, Ser B:Biol Sci 270:407-415.

TURBEVILLE JM, RUPPERTEE (1985). Comparative ultrastructure and the evolution of nemertines. Amer Zool 25:53-71.

TURBEVILLE JM (1986). An ultrastructural analysis of coelomogenesis in the hoplonemertine Prosorhochmus americanus and the polychaete Magelona sp. J Morphol 187:51-60.

TURBEVILLE JM (1991). Nemertinea. In Microscopic anatomy of invertebrates (Eds Harrison FW and Bogitsch BJ) Wiley-Liss, New York, pp. 285-328.

TURBEVILLE JM, FIELD GK, RAFF RA (1992). Phylogenetic position of phylum Nemertini, inferred from 18S rRNA sequences: molecular data as a test of morphological character homology. Mol Biol Evol 9:235-249.

WICKHAM DE (1979). Predation by the nemertean Carcinonemertes errans on eggs of the Dungeness crab Cancer magister. Mar Biol 55: 45-53.

VON DASSOW G, EMLET RB, MASLAKOVA SA (2013). How the pilidium larva feeds. Fronti. Zool. 10: 47.

VON DÖHREN J (2011). The fate of the larval epidermis in the Desor larva of Lineus viridis (Pilidiophora, Nemertea) displays a historically constrained functional shift from planktotrophy to lecithotrophy. Zoomorphology 130: 189-196. 


\section{Further Related Reading, published previously in the Int. J. Dev. Biol.}

Brachyury, Tbx2/3 and sall expression during embryogenesis of the indirectly developing polychaete Hydroides elegans Cesar Arenas-Mena

Int. J. Dev. Biol. (2013) 57: 73-83

http://dx.doi.org/10.1387/ijdb.120056ca

Planarian embryology in the era of comparative developmental biology José M. Martín-Durán, Francisco Monjo and Rafael Romero

Int. J. Dev. Biol. (2012) 56: 39-48

http://dx.doi.org/10.1387/ijdb.113442jm

Evolutionary history of the Tricladida and the Platyhelminthes: an up-to-date phylogenetic and systematic account

Marta Riutort, Marta Álvarez-Presas, Eva Lázaro, Eduard Solà and Jordi Paps

Int. J. Dev. Biol. (2012) 56: 5-17

http://dx.doi.org/10.1387/ijdb.113441mr

Segmentation: mono- or polyphyletic?

Elaine C Seaver

Int. J. Dev. Biol. (2003) 47: 583-595

http://dx.doi.org/10.1387/ijdb.14756334

Ecological regulation of development: induction of marine invertebrate metamorphosis Daniel Jackson, Sally P Leys, Veronica F Hinman, Rick Woods, Martin F Lavin and Bernard M Degnan

Int. J. Dev. Biol. (2002) 46: 679-686

http://dx.doi.org/10.1387/ijdb.12141457

5 yr ISI Impact Factor $(2011)=2.959$
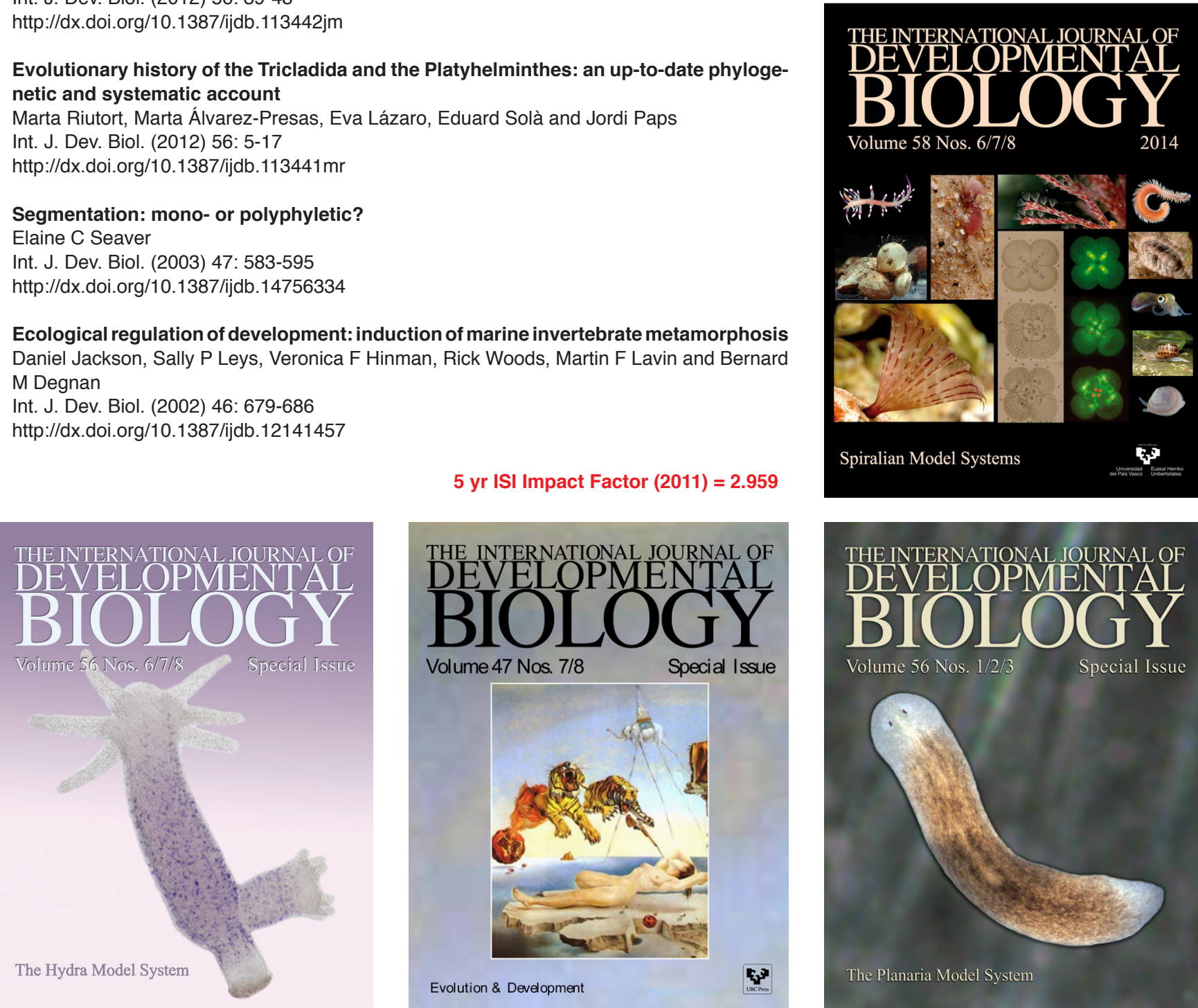

Volume 56 Nos. $1 / 2 / 3$

Special Issue

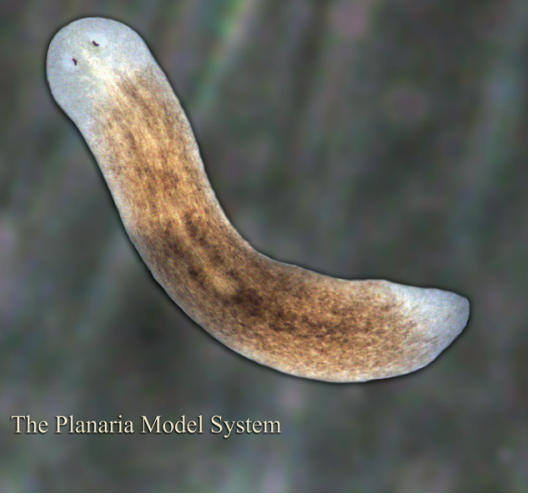

